\title{
The current status of freshwater molluses in the Kruger National Park
}

\author{
C.T. Wolmarans and K.N. DE KOCK
}

Wolmarans, C.T. and K.N. de Kock. 2006. The current status of freshwater molluscs in the Kruger National Park. Koedoe 49(2): 39-44. Pretoria. ISSN 0075-6458.

\begin{abstract}
Surveys regarding the freshwater mollusc population of the Kruger National Park commenced before 1966 and was repeated in 1995, 2001 and recently in 2006. During this period the park was exposed to several droughts as well as floods, all of which could have had some influence on the various habitats in the park. Industrial developments and urbanisation near some of the major rivers outside the park, but which flow through the park, could also have a detrimental effect on the species diversity of the freshwater molluscs. The recent survey in 45 habitats included several dams and rivers. The survey was done to determine the current status of the mollusc species diversity. By comparing it with previous surveys, an attempt was made to establish the overall health of freshwater mollusc habitats. From the results it is clear that there was a drastic decrease in the mollusc species diversity in five of the habitats. Although there was a slight change in the species composition in some of the major rivers there was no difference in the number of species collected in these habitats. Tarebia granifera, an alien invader mollusc, was found in several rivers and dams. Gyraulus costulatus, Melanoides victoriae and Eupera ferruginea, which could not be found during the survey of 2001, were collected during the current survey.
\end{abstract}

Key words: freshwater molluscs, species diversity, rivers, dams, alien invaders.

C.T. Wolmarans and K.N. De kock, School of Environmental Sciences and Development (Zoology), North-West University, Potchefstroom Campus, P/Bag X6001, Potchefstroom, 2520 Republic of South Africa.

\section{Introduction}

The largest diversity of freshwater molluscs is usually present in the tropical and subtropical areas of the world (De Kock et al. 2002). In South Africa, this is especially true for Mpumalanga, Limpopo and KwaZuluNatal (De Kock \& Wolmarans 1998). The Kruger National Park is situated within the first two provinces mentioned. Various species of freshwater snails act as intermediate hosts for trematode parasites (De Kock \& Wolmarans 1998) while they are also known for their ability to act as indicators for water health (Schoonbee 1963). The poor ability of these organisms to migrate, makes them vulnerable to changes in their habitats, such as global warming, pollution or prolonged periods of drought. Although the influence of some of these factors like global warming, is difficult to determine over the short to medium term, the influence of other factors like environmental contamination, may be more evident over a shorter period of time. The degree of these influences on molluscs may also be influenced by a stream, river, small pond or dam. Although the Kruger National Park is recognised worldwide for its conservation efforts, it is not isolated from the factors mentioned above. A number of rivers in the park, including the Letaba, Olifants, Crocodile, Sand and Sabie, meander through adjacent, highly populated and industrialised areas and is it possible that the changes in the water quality occurring in these areas have an effect on the freshwater biodiversity in the park. Molluscs present in isolated habitats may, however, escape such changes. The aim of this investigation was to determine the current status of freshwater molluscs in the park and to compare this with a survey done in 2001 . 


\section{Methods and materials}

This study concentrated mainly on water bodies that had been surveyed for molluscs during the 2001 collection. A few habitats, namely the Mtombeni Spruit, Rabelais Dam (does not exist any more), Lower Sabie rest camp, Tsende Drift, Skukuza fish pond and Jones's Dam were not surveyed. Habitats surveyed for the first time included the Mpanamana Dam, Timbavati River below the Piet Grobler Dam wall, Sabie River below the Lower Sabie Dam wall, Crocodile River, Mbyamiti River (weir), and the Letaba River below the Engelhard Dam wall. A total of 45 habitats were surveyed during 2006. All of these habitat types were screened for molluscs by means of aluminium mollusc scoops. Although a quantitative survey of molluscs was not intended, the same time (man hours) was spent at each of these habitats as in previous surveys in order to recover as many species as possible. The molluscs collected at each habitat were largely full-grown specimens and were transferred to $50 \mathrm{ml}$ glass screw-capped bottles and fixed in $70 \%$ ethanol. Each bottle was provided with a label containing information on date of collection, locality, and collection number. The specimens were identified by means of a stereo microscope and were then added to the National Freshwater Snail Collection (NFSC) located at the North-West University, Potchefstroom Campus.

\section{Results}

The results of this investigation are presented in Table 1. From this it is evident that 11 of the habitats, namely the Crocodile River, Mpanamana Dam, Nhlanganzwane Dam, Ngotso Dam, Letaba River below the Engelhard Dam, Olifants River, Lower Sabie Dam, the Sabie River below the Lower Sabie Dam, the Mbyamiti River (weir), Luvuvhu River and Leeupan were not surveyed in 2001. This was mainly due to a lack of suitable habitats at that time and the fact that some of the habitats were situated in concession areas. Of the 45 habitats surveyed in 2006, no molluses were found in 12 of the habitats, i.e., the Mpanamana, Nhlanganzwane and Ngotso Dams (not surveyed previously), the Nsemani Dam, Shisa Spruit, Vervoer Dam, Manzimahle Dam, Sunset Dam, Sable Dam, Silolweni Dam, Leeupan and the Luvuvhu River. Comparing the 34 habitats surveyed in both 2001 and 2006, it is evident that only the Piet Grobler Dam had no molluscs in 2001. Contrary to this, no molluscs were found in seven of these habitats in 2006, namely the Shisa Spruit, the Nsemani, Vervoer, Manzimahle, Sunset, Sable and Silolweni Dams, four species, not found in 2001 were collected in 2006. Tarebia granifera (an alien invader snail) was found in 12 habitats including several rivers and dams (Table 1). According to the records of the NFSC this species was not previously found in the Kruger National Park. The other three species, namely Gyraulus costulatus, Eupera ferruginea and Melanoides victoriae were found in numerous habitats during the first extensive survey done in 1964. Eupera ferruginea was also found during the 1995 survey. Lanistes ovum and Pisidium pirothi, collected in 2001, were not found during the recent survey. In comparison with the 2001 survey, there was a drastic decrease in the species diversity evident in five of the habitats surveyed in 2006. These include the Matjulu and Shisa spruits, the Engelhard Dam, the Nwanetsi water hole and the Gudzani and Sirheni dams. Whether the presence of the invader $T$. granifera played a role in the decrease in three of these habitats, namely the Engelhard Dam, Nwanetsi water hole and the Gudzani Dam is unknown as it was not found in the remaining three habitats. A drastic increase in species diversity was not experienced in any of the habitats surveyed in 2006. The major rivers (Timbavati, Letaba, and Sabie), showed no significant difference in the mollusc species diversity between the two surveys.

\section{Discussion}

Direct comparisons of the species diversity recorded during the respective surveys could lead to scientifically unfounded conclusions. Aspects that should be taken into account, include amongst others, the number of collections made in a habitat, the exact collection site, the time of the year when the collection was made, as well as the rainfall patterns prior to each survey (De Kock \& Wolmarans 1998). In spite of this, it still seems possible to outline specific trends. Although there was no obvious differences in the number of 
Table 1

Molluscs found in water bodies of the Kruger National Park surveyed in 2001 and 2006

\begin{tabular}{|c|c|c|c|c|}
\hline $\begin{array}{l}\text { Rainfall moni- } \\
\text { toring station }\end{array}$ & Collection site & Grid reference & $\begin{array}{l}\text { Species collected in } \\
2006\end{array}$ & Species collected in 2001 \\
\hline \multirow[t]{2}{*}{ Berg-en-Dal } & Matjulu Spruit & $25^{\circ} 21^{\prime} \mathrm{S} ; 31^{\circ} 31^{\prime} \mathrm{E}$ & $\begin{array}{l}\text { Bulinus globosus } \\
\text { Biomphalaria pfeifferi } \\
\text { Lymnaea columella }\end{array}$ & $\begin{array}{l}\text { Bulinus globosus } \\
\text { Bulinus forskalii } \\
\text { Biomphalaria pfeifferi } \\
\text { Lymnaea natalensis } \\
\text { Lymnaea columella } \\
\text { Aplexa marmorata } \\
\text { Burnupia caffra } \\
\text { Melanoides tuberculata }\end{array}$ \\
\hline & Mlambane Spruit & $25^{\circ} 21^{\prime} \mathrm{S} ; 31^{\circ} 31^{\prime} \mathrm{E}$ & Bulinus globosus & $\begin{array}{l}\text { Bulinus forskalii } \\
\text { Biomphalaria pfeifferi } \\
\text { Aplexa marmorata }\end{array}$ \\
\hline \multirow[t]{5}{*}{$\begin{array}{l}\text { Crocodile } \\
\text { Bridge }\end{array}$} & Gezantombi Dam & $25^{\circ} 20^{\prime} \mathrm{S} ; 31^{\circ} 52^{\prime} \mathrm{E}$ & Bulinus forskalii & Bulinus forskalii \\
\hline & & & Cleopatra ferruginea & $\begin{array}{l}\text { Lymnaea columella } \\
\text { Aplexa marmorata } \\
\text { Burnupia caffra }\end{array}$ \\
\hline & Crocodile River & $25^{\circ} 21^{\prime} \mathrm{S} ; 31^{\circ} 54^{\prime} \mathrm{E}$ & Tarebia granifera & (Not surveyed) \\
\hline & Mpanamana Dam & $25^{\circ} 17^{\prime} \mathrm{S} ; 32^{\circ} 0^{\prime} \mathrm{E}$ & No molluscs found & (Not surveyed) \\
\hline & Nhlanganzwane Dam & $25^{\circ} 14^{\prime} \mathrm{S} ; 31^{\circ} 57^{\prime} \mathrm{E}$ & No molluscs found & (Not surveyed) \\
\hline \multirow[t]{2}{*}{ Houtboschrand } & Timbavati River & $24^{\circ} 31^{\prime} \mathrm{S} ; 31^{\circ} 38^{\prime} \mathrm{E}$ & $\begin{array}{l}\text { Bulinus globosus } \\
\text { Lymnaea natalensis } \\
\text { Gyraulus costulatus }\end{array}$ & $\begin{array}{l}\text { Bulinus africanus } \\
\text { Lymnaea natalensis } \\
\text { Burnupia caffra }\end{array}$ \\
\hline & Ngotso Dam & $24^{\circ} 11^{\prime} \mathrm{S} ; 31^{\circ} 43^{\prime} \mathrm{E}$ & No molluscs found & (Not surveyed) \\
\hline \multirow[t]{3}{*}{ Letaba } & Letaba River & $23^{\circ} 45^{\prime} \mathrm{S} ; 31^{\circ} 22^{\prime} \mathrm{E}$ & $\begin{array}{l}\text { Lymnaea collumella } \\
\text { Physa acuta } \\
\text { Aplexa marmorata } \\
\text { Melanoides tuberculata }\end{array}$ & $\begin{array}{l}\text { Bulinus forskalii } \\
\text { Physa acuta } \\
\text { Melanoides tuberculata }\end{array}$ \\
\hline & Engelhard Dam & $23^{\circ} 50^{\prime} \mathrm{S} ; 31^{\circ} 28^{\prime} \mathrm{E}$ & $\begin{array}{l}\text { Physa acuta } \\
\text { Aplexa marmorata } \\
\text { Tarebia granifera }\end{array}$ & $\begin{array}{l}\text { Bulinus globosus } \\
\text { Bulinus tropicus } \\
\text { Bulinus forskalii } \\
\text { Biomphalaria pfeifferi } \\
\text { Physa acuta } \\
\text { Melanoides tuberculata } \\
\text { Corbicula fluminalis } \\
\text { Pisidium pirothi }\end{array}$ \\
\hline & $\begin{array}{l}\text { Letaba River below the } \\
\text { Engelhard Dam wall }\end{array}$ & $23^{\circ} 31^{\prime} \mathrm{S} ; 31^{\circ} 39^{\prime} \mathrm{E}$ & $\begin{array}{l}\text { Lymnaea columella } \\
\text { Physa acuta } \\
\text { Melanoides tuberculata } \\
\text { Melanoides victoriae } \\
\text { Tarebia granifera } \\
\text { Corbicula fluminalis }\end{array}$ & (Not surveyed) \\
\hline
\end{tabular}

\begin{tabular}{|c|c|c|c|c|}
\hline \multirow[t]{2}{*}{ Lower Sabie } & Olifants River & $24^{\circ} 31^{\prime} \mathrm{S} ; 31^{\circ} 41^{\prime} \mathrm{E}$ & Physa acuta & (Not surveyed) \\
\hline & Mpondo Dam & $25^{\circ} 12^{\prime} \mathrm{S} ; 31^{\circ} 43^{\prime} \mathrm{E}$ & $\begin{array}{l}\text { Bulinus forskalii } \\
\text { Tarebia granifera } \\
\text { Ceratophallus natalensis } \\
\text { Bulinus forskalii }\end{array}$ & $\begin{array}{l}\text { Bulinus forskalii } \\
\text { Lymnaea natalensis } \\
\text { Lymnaea collumella } \\
\text { Spathopsis petersi }\end{array}$ \\
\hline
\end{tabular}


Table 1 (continued)

\begin{tabular}{|c|c|c|c|c|}
\hline & Lower-Sabie Dam & $25^{\circ} 07^{\prime} \mathrm{S} ; 31^{\circ} 56^{\prime} \mathrm{E}$ & Tarebia granifera & ( Not surveyed ) \\
\hline & Sabie River & $25^{\circ} 07^{\prime} \mathrm{S} ; 31^{\circ} 55^{\prime} \mathrm{E}$ & $\begin{array}{l}\text { Bulinus forskalii } \\
\text { Burnupia cf. caffra }\end{array}$ & $\begin{array}{l}\text { Physa acuta } \\
\text { Apexa marmorata }\end{array}$ \\
\hline & $\begin{array}{l}\text { Sabie River below } \\
\text { Lower Sabie Dam wall }\end{array}$ & $25^{\circ} 07^{\prime} \mathrm{S} ; 31^{\circ} 55^{\prime} \mathrm{E}$ & $\begin{array}{l}\text { Tarebia granifera } \\
\text { Corbicula fluminalis } \\
\text { Eupera ferruginea }\end{array}$ & ( Not surveyed ) \\
\hline \multirow[t]{2}{*}{ Mooiplaas } & Pioniers Dam & $23^{\circ} 31^{\prime} \mathrm{S} ; 31^{\circ} 23^{\prime} \mathrm{E}$ & $\begin{array}{l}\text { Bulinus globosus } \\
\text { Biomphalaria pfeifferi } \\
\text { Lymnaea natalensis }\end{array}$ & $\begin{array}{l}\text { Bulinus globosus } \\
\text { Bulinus forskalii } \\
\text { Biomphalaria pfeifferi }\end{array}$ \\
\hline & Grootvlei Dam & $23^{\circ} 20^{\prime} \mathrm{S} ; 31^{\circ} 30^{\prime} \mathrm{E}$ & Bulinus tropicus & Spathopsis sp \\
\hline \multirow[t]{2}{*}{ Nwanetsi } & Nwanetsi water hole & $24^{\circ} 28^{\prime} \mathrm{S} ; 31^{\circ} 58^{\prime} \mathrm{E}$ & $\begin{array}{l}\text { Biomphalaria pfeifferi } \\
\text { Tarebia granifera }\end{array}$ & $\begin{array}{l}\text { Bulinus globosus } \\
\text { Bulinus tropicus } \\
\text { Bulinus forskalii } \\
\text { Biomphalaria pfeifferi } \\
\text { Ceratophallus natalensis } \\
\text { Burnupia caffra } \\
\text { Spathopsis wahlbergi } \\
\text { Spathopsis petersi } \\
\text { Corbicula fluminalis } \\
\text { Melanoides tuberculata } \\
\text { Oxyloma striata }\end{array}$ \\
\hline & Gudzani Dam & $24^{\circ} 22^{\prime} \mathrm{S} ; 31^{\circ} 55^{\prime} \mathrm{E}$ & $\begin{array}{l}\text { Bulinus globosus } \\
\text { Biomphalaria pfeifferi } \\
\text { Lymnaea natalensis } \\
\text { Melanoides tuberculata } \\
\text { Tarebia granifera }\end{array}$ & $\begin{array}{l}\text { Bulinus globosus } \\
\text { Bulinus tropicus } \\
\text { Biomphalaria pfeifferi } \\
\text { Lymnaea natalensis } \\
\text { Ceratophallus natalensis } \\
\text { Melanoides tuberculata } \\
\text { Spathopsis petersi } \\
\text { Corbicula fluminalis }\end{array}$ \\
\hline \multirow[t]{4}{*}{ Pretoriuskop } & Mbyamiti River & $25^{\circ} 13^{\prime} \mathrm{S} ; 31^{\circ} 34^{\prime} \mathrm{E}$ & $\begin{array}{l}\text { Bulinus globosus } \\
\text { Biomphalaria pfeifferi }\end{array}$ & $\begin{array}{l}\text { Bulinus globosus } \\
\text { Lymnaea columella } \\
\text { Aplexa marmorata }\end{array}$ \\
\hline & Mbyamiti River (weir) & $25^{\circ} 15 ' \mathrm{~S} ; 31^{\circ} 37^{\prime} \mathrm{E}$ & $\begin{array}{l}\text { Bulinus globosus } \\
\text { Biomphalaria pfeifferi } \\
\text { Tarebia granifera }\end{array}$ & ( Not surveyed) \\
\hline & Mestel Dam & $25^{\circ} 06^{\prime} \mathrm{S} ; 31^{\circ} 12^{\prime} \mathrm{E}$ & $\begin{array}{l}\text { Bulinus globosus } \\
\text { Melanoides tuberculata } \\
\text { Tarebia granifera }\end{array}$ & $\begin{array}{l}\text { Bulinus globosus } \\
\text { Lymnaea columella } \\
\text { Aplexa marmorata }\end{array}$ \\
\hline & Shitlehave Dam & $25^{\circ} 08^{\prime} \mathrm{S} ; 31^{\circ} 19^{\prime} \mathrm{E}$ & $\begin{array}{l}\text { Bulinus forskalii } \\
\text { Menanoides tuberculata }\end{array}$ & Biomphalaria pfeifferi \\
\hline Punda Maria & Klopperfontein Dam & $22^{\circ} 37^{\prime} \mathrm{S} ; 31^{\circ} 10^{\prime} \mathrm{E}$ & Aplexa marmorata & $\begin{array}{l}\text { Bulinus tropicus } \\
\text { Bulinus forskalii }\end{array}$ \\
\hline \multirow[t]{4}{*}{ Satara } & Nkaya Pan & $24^{\circ} 31^{\prime} \mathrm{S} ; 31^{\circ} 45^{\prime} \mathrm{E}$ & Bulinus forskalii & Bulinus forskalii \\
\hline & Piet Grobler Dam & $24^{\circ} 31^{\prime} \mathrm{S} ; 31^{\circ} 38^{\prime} \mathrm{E}$ & $\begin{array}{l}\text { Bulinus globosus } \\
\text { Tarebia granifera }\end{array}$ & No molluscs found \\
\hline & $\begin{array}{l}\text { Timbavati River below } \\
\text { Piet Grobler Dam wall }\end{array}$ & $24^{\circ} 30^{\prime} \mathrm{S} ; 31^{\circ} 38^{\prime} \mathrm{E}$ & Tarebia granifera & Bulinus forskalii \\
\hline & Nsemani Dam & & No molluscs found & $\begin{array}{l}\text { Bulinus forskalii } \\
\text { Burnupia caffra }\end{array}$ \\
\hline
\end{tabular}


Table 1 (continued)

\begin{tabular}{|c|c|c|c|c|}
\hline \multirow[t]{4}{*}{ Shingwedzi } & Krapkuil Dam & $23^{\circ} 14^{\prime} \mathrm{S} ; 31^{\circ} 18^{\prime} \mathrm{E}$ & Bulinus tropicus & Burnupia caffra \\
\hline & Sirheni Dam & $22^{\circ} 56^{\prime} \mathrm{S} ; 31^{\circ} 14^{\prime} \mathrm{E}$ & $\begin{array}{l}\text { Bulinus globosus } \\
\text { Biomphalaria pfeifferi }\end{array}$ & $\begin{array}{l}\text { Bulinus globosus } \\
\text { Biomphalaria pfeifferi } \\
\text { Lymnaea natalensis } \\
\text { Lymnaea columella } \\
\text { Lanistes ovum }\end{array}$ \\
\hline & Shisa Spruit & $22^{\circ} 57^{\prime} \mathrm{S} ; 31^{\circ} 15^{\prime} \mathrm{E}$ & No molluscs found & $\begin{array}{l}\text { Cleopatra ferruginea } \\
\text { Melanoides tuberculata } \\
\text { Spathopsis petersi } \\
\text { Corbicula fluminalis }\end{array}$ \\
\hline & Kanniedood Dam & $23^{\circ} 08^{\prime} \mathrm{S} ; 31^{\circ} 27^{\prime} \mathrm{E}$ & $\begin{array}{l}\text { Spathopsis wahlbergi } \\
\text { Spathopsis petersi }\end{array}$ & $\begin{array}{l}\text { Bulinus tropicus } \\
\text { Bulinus forskalii } \\
\text { Lymnaea natalensis }\end{array}$ \\
\hline \multirow[t]{4}{*}{ Skukuza } & Olifantdrinkgat & $24^{\circ} 53^{\prime} \mathrm{S} ; 31^{\circ} 44^{\prime} \mathrm{E}$ & Bulinus forskalii & Bulinus forskalii \\
\hline & Vervoer Dam & $25^{\circ} 07^{\prime} \mathrm{S} ; 31^{\circ} 29^{\prime} \mathrm{E}$ & No molluscs found & $\begin{array}{l}\text { Lymnaea columella } \\
\text { Aplexa marmorata }\end{array}$ \\
\hline & Manzimahle Dam & $24^{\circ} 53^{\prime} \mathrm{S} ; 31^{\circ} 43^{\prime} \mathrm{E}$ & No molluses found & Bulinus forskalii \\
\hline & Sunset Dam & $25^{\circ} 06$ 'S; $31^{\circ} 54^{\prime} \mathrm{E}$ & No molluscs found & Aplexa marmorata \\
\hline \multirow[t]{7}{*}{ Phalaborwa } & Sable Dam & $23^{\circ} 56^{\prime} \mathrm{S} ; 31^{\circ} 14^{\prime} \mathrm{E}$ & No molluses found & $\begin{array}{l}\text { Bulinus tropicus } \\
\text { Bulinus forskalii }\end{array}$ \\
\hline & Orpen Dam & $24^{\circ} 47^{\prime} \mathrm{S} ; 31^{\circ} 53^{\prime} \mathrm{E}$ & Aplexa marmorata & $\begin{array}{l}\text { Lymnaea columella } \\
\text { Ceratophallus natalensis }\end{array}$ \\
\hline & Mazithi Dam & $24^{\circ} 43^{\prime} \mathrm{S} ; 31^{\circ} 50^{\prime} \mathrm{E}$ & Bulinus forskalii & Bulinus forskalii \\
\hline & Kumana dam & $24^{\circ} 37^{\prime} \mathrm{S} ; 31^{\circ} 47^{\prime} \mathrm{E}$ & Bulinus forskalii & Bulinus forskalii \\
\hline & Nwaswitsontso River & $24^{\circ} 37^{\prime} \mathrm{S} ; 31^{\circ} 47^{\prime} \mathrm{E}$ & Bulinus forskalii & Bulinus forskalii \\
\hline & Silolweni Dam & $24^{\circ} 29^{\prime} \mathrm{S} ; 31^{\circ} 50^{\prime} \mathrm{E}$ & No molluses found & $\begin{array}{l}\text { Bulinus forskalii } \\
\text { Burnupia caffra }\end{array}$ \\
\hline & Leeupan & $24^{\circ} 50^{\prime} \mathrm{S} ; 31^{\circ} 48^{\prime} \mathrm{E}$ & No molluses found & (Not surveyed) \\
\hline Pafuri & Luvuvhu River & $22^{\circ} 26^{\prime} \mathrm{S} ; 31^{\circ} 13^{\prime} \mathrm{E}$ & No molluscs found & (Not surveyed) \\
\hline
\end{tabular}

species found in the larger rivers (Timbavati, Letaba and Sabie Rivers) when comparing the 2001 and 2006 surveys, slight changes in the species diversity were evident (Table 1). This may be an indication that any changes in the water quality of these rivers before entering the park, still did not have a noticeable effect on the mollusc species diversity in these habitats. The presence of Physa acuta (also known as the sewage snail, Apple- ton 2003) the second-most successful alien invader mollusc species in South Africa (De Kock et al. 1989) in the Olifants River, may be an indication of the abnormal conditions in this river. The unfavourable $\mathrm{pH}$ of the water due to old mine activities, the pollution contributed by various industries in the Witbank area, and poor farming practises where overgrazing causes top soil to wash into the river, all create a situation where $P$. acuta may be 
one of the few species able to survive. The occurrence of a number of floods in this river since 1995 should have enhanced the overall water quality but did not contribute much to the increase in species diversity of molluscs recovered. The fact that there was a decrease in species diversity of molluscs in a number of habitats and that no snails were found in several of the dams also surveyed in 2001 (Table 1) could either be ascribed to a decrease in the overall number of molluscs in these dams due to a lack of suitable habitats or to environmental influences like specific rainfall patterns directly before the survey. As these dams are not connected to rivers arising outside the park, it seems highly improbable that industrial pollution could play a significant role in this phenomenon. The presence of $T$. granifera in a number of habitats in which it was not previously found, could be reason for great concern especially if its presence would have a detrimental effect on the survival of other freshwater fauna. This is an aspect that should, in our opinion, be investigated in great depth. Although the increase in species diversity found in 2001 as compared to the survey of 1995 was ascribed to the high rainfall average between 1995 and 2001 (De Kock et al. 2002) the recent survey was done shortly after a period of high rainfall. It is, however, important to keep in mind that the actual period between the last significant rainfall and the time of the survey may play a role in the species diversity and it is therefore premature to conclude that there was a decrease in the general species diversity as far as the freshwater molluscs are concerned. Therefore more surveys should be done to clarify the reasons for the decrease in species diversity recently encountered.

\section{Conclusions}

Comparisons between the respective habitats surveyed in 2001 and 2006 revealed slight differences in the mollusc species diversity of the Letaba, Timbavati and Sabie Rivers but no differences in the number of species collected. Although there was a decrease in the mollusc species diversity in five of the habitats during the 2006 survey and no molluscs were found in another 12 habitats as compared to only one during the 2001 survey, it would seem premature to conclude that there was an overall decrease in the species diversity. The occurrence of T. granifera in 12 of the habitats is a matter of concern especially because of its ability to invade a variety of habitats in a relatively short period, a situation that should be monitored very closely in the future.

\section{Acknowledgements}

The authors wish to thank the following persons and institutions for their assistance: The National Parks Board for permission to conduct the research, as well as for their financial support; Mr Hendrik Sithole who was instrumental in assisting us with the necessary arrangements for the survey; the Research Focus Area, Environmental Science and Sustainable Management of the Potchefstroom Campus of the North-West University for financial support.

\section{References}

Appleton, C.C. 2003. Alien and invasive fresh water Gastropoda in South Africa. African Journal of Aquatic Science 28: 69-81.

De Kock, K.N., P.H. Joubert \& S.J. Pretorius. 1989. Geographical distribution and habitat preferences of the invader freshwater snail species Lymnaea columella (Mollusca: Gastropoda) in South Africa. Onderstepoort Journal of Veterinary Research 56: 271-275.

De Kock, K.N. \& C.T. Wolmarans. 1998. A re-evaluation of the occurrence of freshwater molluscs in the Kruger National Park. Koedoe 41(1): 1-8.

De Kock, K.N., C.T. Wolmarans \& L.H. Du Preez. 2002. Freshwater mollusc diversity in the Kruger National Park: a comparison between a period of prolonged drought and a period of exceptionally high rainfall. Koedoe 45(2): 1-11.

SchoonbeE, H.J. 1963. Pollution studies in the Umgeni River, Part 3: A study of the biological and chemical effects of effluent discharges in the Pinetown-New Germany Industrial complex. C.S.I.R. spec. Rep., W25, 1-34. 